\title{
Bioenergy - a Sustainable and Reliable Energy Source
}

\author{
Manuel Paneque* \\ Department of Environmental Sciences and Natural Resources, University of Chile, Chile
}

Submission: February 27, 2017; Published: March 02, 2017

"Corresponding author: Manuel Paneque, Department of Environmental Sciences and Natural Resources, Faculty of Agricultural Sciences, University of Chile, Santa Rosa 11,315, La Pintana, 8820808 Santiago, Chile, Tel: +56-2-2978-5863; Email: mpaneque@uchile.cl

\section{Opinion}

Chile needs to diversify its energy matrix for environmental and strategic reasons. To encourage the development NonCoventional Renewable Energy (NCRE) is country's necessity in order to increase the supply security, diversify the sources of production and reduce external dependence, also to promote the sustainable development of the energy sector, due to their lower environmental impact compared to traditional forms of electricity generation [1].

Oil and its derivatives contribute 55\% of Chile's energy matrix, and will account for $67 \%$ by $2030[2,3]$. The emission of greenhouse gases that result from the burning of these fuels is one of the primary causes of global warming. Chile is committed to reducing in $20 \%$ its greenhouse gas emissions for 2020 , in respect to the base scenario of 2007 and also to lift the existing barriers towards NCRE, taking the compromise that in 2025, $20 \%$ of the energy injections proceed from NCRE [4]. However, according to current trends, a $360 \%$ increase in carbon dioxide (CO2) emissions is expected, both in electricity generation and transportation; currently $0.3 \%$ of the total world emission $[3,5]$.

The $20 \%$ of the primary energy consumed in Chile comes from firewood, which is the third most important source of energy after oil and gas [6]. Firewood represents $60 \%$ of the national energetic sources of residual use and does not currently have an accessible and competitive substitute for the population [7]. Its final use, in general, is for residential heating and cooking, over $90 \%$ of the south-central zone of Chile uses a firewood artefact $[6,7]$. The use of firewood gives an economic value to the forest, this is an essential characteristic if the sustainable exploitation of this resource seeks to be promoted.

For this reason, the Chilean energy sector faces the challenge of boosting and sustaining economic growth. As well as administrating energy costs, ensuring reliability, providing universal access to the electrical system and meeting increasingly ambitious environmental goals. These difficulties could be solved successfully if Chile turns decisively towards a path of growth funded on renewable energy. A system with greater presence of these kinds of energy results in lower amounts of pollutant emissions.

In their Energy Policy, the government has proposed lifting the existing barriers to NCREs, promising that $45 \%$ of the generation capacity to be installed in the country between 2014 and 2025 will come from unconventional energy sources [3]. $13.5 \%$ of the current energy matrix corresponds to NCRE, with 2,975 MW of generation in Chile. Eolic energy accounts for $34.6 \%$ of NCREs installed power, followed by solar energy which contributes $35 \%$, bioenergy power plants $15.4 \%$, and small-hydro power plants $15 \%$. A total of 39 NCRE projects are currently under construction, totaling 1,640 MW of power, and are due to enter into operation before August 2018. Solar plant projects totaling 1,348 MW of power are under construction, of which 1,238 MW are solar photovoltaic and $110 \mathrm{MW}$ solar concentration. In addition to $208 \mathrm{MW}$ of eolic projects, $48 \mathrm{MW}$ of geothermal projects, and $36 \mathrm{MW}$ of projects of small-hydro power plants [8].

The Chilean forestry sector actively participates in the generation of electricity and renewable energies from the byproducts of the timber industry [9]. Through the combustion of branches, barks, chips and black liquor, companies not only generate electricity for their own consumption, but also inject their surplus into the Central Interconnected System [1]. This biomass energy has $459 \mathrm{MW}$ of installed capacity and, in terms of generation, biomass is the renewable source with the lowest participation in the injections towards the energy matrix, with 79 GWh [8].

Biomass can be considered both for large projects or smaller plans, and has the advantage of solving environmental problems. For example, in the fields it is an alternative to the agricultural burning of field residue and evades the otherwise negative 
effects that this practice has on the environment, such as greenhouse gas emissions. We highlight its operational flexibility in thermoelectric plants; since they operate all year round, therefore they do not suffer from problems of intermittency except for maintenance, in contrast to other energy sources which vary throughout the day, such as solar and eolic. This has allowed biomass to become the NCRE which supplies the most energy to the national matrix. However, both political leadership and growth-promoting stimuli are absent in this sector.

The use of biomass is economically, socially and environmentally advantageous, since when coming from sustainably managed forests, the total carbon released during its combustion is the same as what the trees captured during their growth, making it a non-polluting carbon neutral fuel [10]. However, regardless of the low bioenergy potential of the forest resource, it is necessary to stimulate a policy of encouraging the creation of more plantations to increase available biomass, whether it be for the production of wood, bioenergy, firewood, non-wood products or the recovery of eroded soils, since in any of these cases the generated biomass acts as carbon catcher.

Energy from biomass contributes significantly to the national energy balance and since Chile is a major agricultural producer, the dendroenergetic potential is very significant, it is therefore, essential that the country considers dendroenergy in its energy strategy and stimulates policies which promote the energetic use of biomass. Chile's potential area for the establishment of dendroenergy plantations reaches 2.05 million hectares $[9,11,12]$. In addition, there are at least 3 million hectares of eroded soil in the country that can be forested, along with significant areas of manageable native forests, of which approximately half have no other viable use than to generate energy, given their poor quality because of rotting. The arid north also has over 1 million hectares of land with potential for integration into bioenergy and carbon capture projects [1,11-13].

The enhancement of marginal land and extension of the agricultural frontier can contribute towards mitigating climate change, providing a new productive alternative and foster the development of isolated and impoverished rural areas [13-15]. Bioenergy and energy crops allow to revalue these soils, and with their contribution they not only improve the quality of life for those who produce them, but create a flag under which to fight against climate change, desertification and energy dependence $[14,16]$.

In the coming decades, Chile can meet its energy demands through a variety of NCRE sources and energy efficient technologies that complement its current production base. It is necessary to change our relationship with the earth, letting traditional technologies to be replaced by new ones, that are more compatible with our environment. This same paradigm demands that we embark today upon a development path that permits long term growth, to this end it is essential to incorporate into public and economic policies priorities of environmental and social welfare. However, this will only be possible if our country strengthens its institutions, innovates in energy efficiency policies to remove existing barriers and more effectively promotes the development of all energy sectors, including bioenergy.

\section{Conflicts of Interest}

The author declares no conflict of interest.

\section{References}

1. Paneque M, Román C, Vásquez-Paniza R, Arriaza JM, Morales D, et al. (2011) Bioenergía en Chile. In: M Paneque (Ed.), Universidad de Chile, Santiago, Chile, pp. 124.

2. Román-Figueroa C, Paneque M (2015) Ethics and BiofuelProduction in Chile. J Agr Environ Ethic 28(2): 293-312.

3. Ministerio de Energía (2016a) Energía 2050. Política Energética de Chile.

4. Bachelet M (2014) Conferencia de las Partes en la Convención Marco de Las Naciones Unidas sobre Cambio Climático (COP20), Lima (Perú).

5. Chile Sustentable (2013) Energía en Chile ¿Para qué y para quién?

6. Ministerio de Energía (2016b) Política de uso de la leña y sus derivados para calefacción.

7. Ministerio de Energa (2015) Medición del consumo nacional de leña y otros combustibles sólidos derivados de la madera.

8. Comisión Nacional de Energía (2017) Monthly NRCE Report (CNE).

9. Acevedo R (2013) La Tercera.

10. Grupo Intergubernamental de Expertos sobre el Cambio Climático (2005) La captación y el almacenamiento de dióxido de carbono. Bert Metz, et al. (Ed).

11. Uribe JM, Cabrera R, de la Fuente A, Paneque M (2012) Atlas bioclimático de Chile. M Paneque (Ed.), Universidad de Chile, Santiago, Chile, pp. 228.

12. Román-Figueroa C, Padilla R, Uribe JM, Paneque M (2017a) Land suitability assessment for camelina (Camelina sativa L.) development in Chile. Sustainability 9(1): 154-168.

13. Zulantay M, Paneque M, Román-Figueroa C, Uribe JM, Celis C, et al. (2013) Biomasa en el Desierto de Chile. Paneque M (Ed.), Universidad de Chile, Santiago, Chile, pp. 128.

14. Román C, Vásquez K, Martínez G, Lillo G, Fuster R, et al. (2012) Cultivos energéticos una apuesta de futuro. Paneque M (Ed.), (2a edn), Universidad de Chile, Santiago, Chile, pp. 224.

15. Román-Figueroa C, Montenegro N, Paneque M (2017b) Bio energy potential from cropresidue biomass in Araucania Region of Chile. Renewable Energy 102 (Part A): 170-177.

16. Valdés D (2016) El Mercurio de Calama. 
This work is licensed under Creative Commons Attribution 4.0 License DOI: $10.19080 /$ ARTOAJ.2017.04.555642

\section{Your next submission with Juniper Publishers} will reach you the below assets

- Quality Editorial service

- Swift Peer Review

- Reprints availability

- E-prints Service

- Manuscript Podcast for convenient understanding

- Global attainment for your research

- Manuscript accessibility in different formats ( Pdf, E-pub, Full Text, Audio)

- Unceasing customer service

Track the below URL for one-step submission https://juniperpublishers.com/online-submission.php 